IMKA Implementasi Manajemen \& Kewirausahaan

Vol. 1, No. 1 (April 2021): 20-29

\title{
Pengaruh Lingkungan Kerja dan Karakteristik Individu terhadap Kinerja Karyawan pada PT. Karya Indah Alam Sejahtera di Gresik
}

\author{
Ayu Puspita Dewi \\ PT. Karya Indah Alam Sejahtera \\ aipuspita1992@gmail.com
}

\begin{abstract}
The purpose of this study was to determine the effect of work environment, individual characteristics, on employee performance at PT. Karya Indah Alam Sejahtera in Gresik. The type of research used by researchers is explanatory research with a quantitative research approach. The population in this study were 523 people who were included in the internal employees of the company PT. Karya Indah Alam Sejahtera in Gresik and the samples in this study were 84 people. The results showed that the work environment and individual characteristics had an effect on employee performance. The work environment and individual characteristics simultaneously also have a significant and positive influence on employee performance.
\end{abstract}

Keywords: Individual characteristics, work environment and employee performance.

\begin{abstract}
Abstrak: Tujuan dari penelitian ini adalah untuk mengetahui pengaruh lingkungan kerja, karakteristik individu, terhadap kinerja karyawan pada PT. Karya Indah Alam Sejahtera di Gresik. Jenis penelitian yang digunakan oleh peneliti adalah explanatory research dengan pendekatan penelitian kuantitatif. Populasi dalam penelitian ini adalah 523 orang yang termasuk dalam karyawan internal perusahaan PT. Karya Indah Alam Sejahtera di Gresik dan yang menjadi sampel dalam penelitian ini sebanyak 84 orang. Hasil penelitian menunjukkan bahwa lingkungan kerja dan karakteristik individu berpengaruh terhadap kinerja karyawan. Lingkungan kerja dan karakteristik individu secara simultan juga mempunyai pengaruh yang signifikan dan positif terhadap kinerja karyawan.
\end{abstract}

Kata Kunci: Karakteristik individu, lingkungan kerja dan kinerja karyawan. 


\section{PENDAHULUAN}

Para pengusaha berusaha meningkatkan serta mengembangkan perusahaannya dengan mengadakan berbagai cara yang tersusun dalam program untuk meningkat kinerja para karyawan. Kinerja menurut dari Rivai dan Basri yang di kutip dari Kaswan (2012) dalam bukunya, menjelaskan bahwa kinerja adalah hasil atau tingkatan keberhasilan seseorang secara keseluruhan selama periode tertentu di dalam melaksanakan tugas di bandingkan dengan kemungkinan seperti standart kerja, target, atau saran kinerja yang telah disepakati bersama.

Kinerja dari seorang karyawan dapat dilihat dari kegiatan karyawan itu sendiri, seperti hasil kerja yang dihasilkan, kecakapan, dan kualitas pekerjaan. Hal ini sangat diperhatikan untuk meningkatkan kinerja dari karyawan. Apa yang telah karyawan lakukan untuk perusahaan selama ini akan dibuat sebagai standar dari rata-rata karyawan. Standar yang telah di dapatkan akan di buat sebagai tolak ukur penilaian yang di lakukan oleh manajemen. Meningkatnya kinerja dari karyawan maka akan dapat menimbulkan dampak positif terhadap produktfitas perusahaan, dan tercapai nya tujuan-tujuan perusahaan. Maka dari itu kinerja dari karyawan harus dapat diperbaiki menjadi lebih baik. Banyak faktor yang terkait dalam perbaikan kinerja karyawan. Salah satunya adalah menciptakan keadaan yang nyaman dalam bekerja, yaitu yang berhubungan dengan lingkungan kerja secara langsung maupun tidak langsung dengan karyawan. Lingkungan kerja dapat berpengaruh positif dan juga negatif terhadap kinerja dari karyawannya. Oleh karena itu lingkungan kerja juga menjadi perhatian dalam perbaikan kinerja karyawan.

Lingkungan kerja menurut dari Sedarmayanti (2011) dijelaskan sebagai keseluruhan alat perkakas dan bahan yang di hadapi lingkungan sekitarnya dimana seseorang bekerja, metode kerjanya dan pengaturan kerjanya baik sebagai perseorangan maupun sebagai kelompok. Suatu lingkungan kerja dapat di katakan baik jika karyawannya dapat menjalankan suatu kegiatan secara optimal, sehat, aman serta nyaman. Sedarmayanti (2011) membagi lingkungan kerja menjadi dua, yaitu lingkungan kerja fisik dan lingkungan kerja non fisik. Pada lingkungan kerja fisik terbagi lagi menjadi dua, yaitu lingkungan kerja fisik secara langsung dan lingkungan kerja fisik tidak langsung. Contoh dari lingkungan fisik seperti tempat kerja dan meja kursi nya, suhu dan udara di dalam kerja, sirkulasi udara, dan kebisingan suara. Sedangkan contoh dari lingkungan kerja non fisik seperti hubungan antara atasan dan bawahan.

Faktor selanjutnya yang menjadi perhatian adalah karakteristik individu dari tiap karayawan. Karakter dari karyawan nanti akan dikelompokkan ke dalam beberapa bagian, sehingga dapat mengetahui apa yang menjadi potensi karyawan itu sendiri. Karakterkarakter tersebut adalah karakteristik individu yang dimiliki oleh seorang karyawan. Menurut dari Hurriyati (2010) menjelasan bahwa karakteristik individu merupakan suatu proses psikologi yang mempengaruhi individu dalam memperoleh, mengkonsumsi serta 
menerima barang dan jasa serta pengalaman. Pengenalan karakter dari karyawan juga dapat untuk mengetahui sudah cocok atau belum penempatan karyawan dengan bidang pekerjaan yang dikerjakan di perusahaan. Jika karyawan tersebut telah cocok antara bagian pekerjaannya dengan karakter individunya maka kinerja yang akan dihasilkan akan maksimal dengan sendirinya. Hal ini merupakan tugas dari human resources department yang memegang peranan penting untuk mendapatkan karyawan yang sesuai dengan kemampuannya. Karakteristik individu dari seseorang akan berpengaruh besar terhadap kerjasama dalam pekerjaan diperusahaan, karena faktor manajemen yang sangat penting adalah faktor tenaga manusia. Dari setiap individu mempunyai karakteristik sendiri-sendiri yang berbeda antara individu yang satu dan yang lainnya. Ada yang karakternya kurang sesuai dengan job description pekerjaan yang dikerjakan. Karakteristik individu akan terbentuk dari faktor bawaan yang sudah ada secara biologis maupun terbentuk karena faktor lingkungan dimana dia tinggal atau bekerja. Karakter seseorang yang sudah baik akan menghasilkan banyak ide-ide yang baik untuk kemajuan suatu pekerjaan yang otomatis akan berdampak dengan peningkatan kinerja. Sebaliknya juga jika karakter seseorang kurang baik atau karakter dari seseorang tersebut tidak sesuai dengan bidang pekerjaannya, tidak menutup kemungkinan tidak akan dapat mengeluarkan ide-ide atau kinerja dengan maksimal.

Hal ini menjadi perhatian penting dari bagian human resources department selaku bagian yang berhubungan dengan sumber daya manusia yang bekerja di suatu perusahaan. Dalam suatu perusahaan ada beberapa divisi atau bagian yang di tempati oleh orang-orang pilihan yang dengan sengaja dipilih untuk menempati bagian tersebut, agar dari sumber daya manusia atau pekerja dapat mengeluarkan segala kemampuan dan skillnya sehingga bisa meningkatkan kinerja karyawan itu sendiri. Berdasarkan uraian tersebut dapat dikatakan bahwa kinerja merupakan hasil dari karyawan berupa kuantitas maupun kualitas yang dibandingkan dengan standart dari perusahaan, dan dapat diwujudkan dengan peran dari perusahaan, disini juga sangat penting untuk meningkatkan lingkungan kerja dan pengenalan karakteristik individu dari karyawan yang bekerja di perusahaan demi tercapainya tujuan-tujuan perusahaan. Penelitian ini diambil pada perusahaan penghasil minyak goreng di daerah Gresik, Jawa timur. Dalam menjalankan dan mengembangkan perusahaan, maka sangat di butuhkan karyawan yang memilki kinerja yang tinggi, cakap, dan terampil. Bukan hanya melihat dari segi kinerja saja yang harus diperhatikan tetapi faktor dari lingkungan kerja juga harus menjadi perhatian oleh perusahaan. Tidak ketinggalan juga faktor karakteristik individu juga menjadi perhatian bagi perusahaan untuk penempatan orang-orang yang berkompeten di bidangnya. 


\title{
TINJAUAN TEORITIS
}

\author{
Kinerja Karyawan
}

Menurut Mangkunegara (2012) dalam bukunya yang berjudul Manajemen Sumber Daya Manusia Perusahaan, kinerja merupakan hasil kerja yang dilihat dari kualitas dan kuantitas yang dicapai oleh seorang karyawan dalam menjalankan tugasnya masingmasing sesuai dengan tanggung jawabnya. Menurut ahli yang lain, Sedarmayanti (2011) mendefinisikan kinerja merupakan terjemahan dari performance yang berarti hasil seorang pekerja, sebuah proses manajemen atau suatu organisasi secara keseluruhan, dimana hasil kerja tersebut harus dapat ditunjukkan buktinya secara konkrit dan dapat diukur (dibandingkan dengan standart yang telah ditentukan). Sedangkan menurut Wibowo (2010) mengemukakan bahwa kinerja adalah tentang melakukan pekerjaan dari hasil yang dicapai dari pekerjaan tersebut.

Menurut Kaswan (2012) kinerja dianggap sebagai hasil atau tingkat keberhasilan seseorang keseluruhan selama periode tertentu di dalam melaksanakan tugas dibandingkan dengan kemungkinan, seperti standart hasil kerja, target atau sasaran, atau kriteria yang telah ditentukan terlebih dahulu dan telah disepakati bersama. Dari beberapa pengertian tersebut, dapat dikemukakan bahwa kinerja adalah suatu hasil kerja yang dicapai oleh seorang karyawan sesuai dengan standart dan kriteria yang telah ditetapkan dalam kurun waktu tertentu dalam suatu organisasi agar tercapai tujuan yang diinginkan suatu organisasi dan meminimalisir kerugian. Dan adapula yang mengartikan sebagai kesediaan seseorang atau kelompok orang untuk melakukan sesuatu kegiatan dan menyempurnakannya sesuai dengan tanggung jawabnya dengan hasil seperti yang di harapkan.

\section{Lingkungan Kerja}

Lingkungan kerja adalah segala alat perkakas dan juga bahan yang di hadapi, lingkungan di sekitarnya yang mana pekerja bekerja, metode kerjanya dan pengaturan kerjanyan baik dia melakukkan perseorangan ataupun berkelompok (Sedarmayanti, 2011). Sedangkan menurut Sofyan (2013) lingkungan kerja adalah segala sesuatu yang berada di sekitar karyawan yang mempengaruhi dirinya dalam menjalankan dan menyelesaikan tugas-tugas yang diberikan kepadanya dalam suatu wilayah Lingkungan kerja yang baik yaitu apabila karyawan dapat melaksanakan kegiatan secara optimal, sehat, aman dan nyaman. Lingkungan kerja yang kurang baik dapat menuntut tenaga kerja serta waktu yang lebih banyak dan tidak mendukung di perolehnya rancangan sistem kerja yang efisien.

Menurut Mangkunegara (2012) pengertian lingkungan kerja adalah uraian mengenai jabatan yang jelas, baik target kerja, komunikasi, iklim dalam kerja dan fasilitasnya. Berdasarkan penjelasan tersebut dapat diambil kesimpulan bahwa lingkungan kerja adalah kehidupan sosial, psikologi, dan fisik dalam perusahaan yang berpengaruh terhadap pekerja dalam melaksanakan tugasnya. Kehidupan manusia tidak 
terlepas dari berbagai keadaan lingkungan sekitarnya, antara manusia dan lingkungan terdapat hubungan yang erat. Selama melakukan pekerjaan, setiap pekerja akan berinteraksi dengan berbagai kondisi yang terdapat di lingkungan kerja.

Secara garis besar lingkungan kerja dibagi menjadi dua yaitu lingkungan kerja fisik dan lingkungan kerja non fisik, hal ini sesuai dengan penjelasan dari Sedarmayanti (2011) dalam bukunya, menjelaskan sebagai berikut:

a. Lingkungan kerja fisik yaitu semua keadaan berbentuk fisik yang terdapat di sekitar tempat kerja dimana dapat mempengaruhi karyawan baik secara langsung maupun tidak langsung. Lingkungan kerja fisik sendiri di bagi lagi dalam 2 kategori, yaitu: 1) Lingkungan kerja yang langsung berhubungan dengan karyawan, seperti meja kursi kantor, ruang kerja dan sebagainya. 2) Lingkungan perantara atau lingkungan umum dapat juga di sebut lingkungan kerja yang mempengaruhi kondisi manusia, misalnya temperatur udara, kelembaban, sirkulasi udara, pencahayaan, kebisingan, getaran mekanis, dan lain sebagainya. Dengan begitu berpengaruhnya lingkungan kerja fisik pada seorang karyawan sangat erat sekali, jadi tidak bisa di anggap remeh. Di butuhkan banyak kajian untuk bisa menciptakan lingkungan kerja fisik yang sesuai dengan tipe pekerjanya, sehingga bisa meningkatkan kinerja dari karyawan itu sendiri.

b. Lingkungan kerja non fisik yaitu semua keadaan yang terjadi yang berkaitan dengan hubungan kerjasama antara tingkat atasan, bawahan maupun yang memiliki status jabatan yang sama di perusahaan. Kondisi yang hendaknya diciptakan adalah suasana kekeluargaan, komunikasi yang baik, dan pengendalian diri. Perusahaan hendaknya dapat menciptakan kondisi yang mendukung kerjasama antar semua tingkat, jadi lingkungan kerja non fisik juga merupakan kelompok lingkungan kerja yang tidak bisa diabaikan.

Menurut dari Sedarmayanti (2011) menjelaskan manfaat lingkungan kerja adalah menciptakan gairah kerja, sehingga produktivitas dan prestasi kerja meningkat. Sementara itu, manfaat yang diperoleh karena bekerja dengan orang - orang yang termotivasi adalah pekerjaan yang dapat terselesaikan dengan tepat, yang artinya pekerjaan yang diselesaikan sesuai standart yang benar dan dalam skala waktu yang di tentukan. Dan dengan sendirinya kinerja dari seorang karyawan akan meningkat. Situasi dimana kondisi lingkungan kerja yang dikatakan baik atau sesuai dengan kondisi manusia nya sendiri yang ada di dalam maupun di luarnya dapat melaksanakan kegiatannya dengan maksimal. Karyawan akan mampu melaksanakan kegiatannya dengan optimal apabila ditunjang dengan suatu lingkungan kerja yang baik. Berikut ini beberapa faktor yang mempengaruhi lingkungan kerja, menurut dari Sedarmayanti (2011) dalam bukunya menjelaskan yang dapat mempengaruhi terbentuknya suatu kondisi lingkungan kerja diantaranya adalah:

a. Penerangan atau cahaya di tempat kerja. Cahaya atau penerangan di tempat kerja merupakan hal yang sangat penting untuk keselamatan dalam bekerja, oleh karena itu di butuhkan cahaya yang terang tetapi tidak menyilaukan. Pada dasarnya cahaya di bedakan menjadi empat, yaitu; cahaya langsung, cahaya setengah langsung, cahaya tidak langsung, dan cahaya setengah tidak langsung. 
b. Temperatur di tempat kerja. Temperatur di tempat kerja di anjurkan untuk bisa sesuai dengan keadaan pekerjaan yang ada, tetapi tiap individu bisa berbeda - beda dalam beradaptasi dengan faktor temperature di suatu tempat kerja. Dalam keadaan normal, suhu tubuh manusia mempunyai temperature yang berbeda dan berusaha untuk kembali pada suhu normal pada tempat yang berbeda pula.

c. Kelembaban di tempat kerja. Kelembaban pada dasarnya adalah kandungan air di dalam udara, biasanya di nyatakan dalam prosentase. Kelembaban ini di pengaruhi juga oleh faktor temperature udara, panas, dan aliran udara.

d. Sirkulasi di tempat kerja. Perputaran udara yang ada di suatu ruangan, udara yang kurang baik bertukar dengan udara yang bagus dan kadar oksigennya tinggi. Sumber udara yang bagus adalah berasal dari tanaman hijau, yang mungkin bisa di tanam di sekitar tempat kerja.

e. Kebisingan di tempat kerja yaitu bunyi-bunyian dengan intensitas yang tinggi dan bervolume yang keras dan sifatnya mengganggu. Kebisingan merupakan salah satu polusi yang ada dan cukup sulit untuk diatasi. Terlalu sering mendapatkan kebisingan akan membuat tingkat konsentrasi pada pekerjaan juga akan menurun.

Berdasarkan uraian di atas, dan penelitian terdahulu, maka bisa disusun hipotesis lingkungan kerja mempunyai pengaruh yang signifikan terhadap kinerja karyawan pada PT. Karya Indah Alam Sejahtera di Gresik.

\section{Karakteristik Individu}

Karakteristik individu adalah ciri khas yang menunjukkan perbedaan seseorang tentang motivasi, inisiatif, kemampuan untuk tetap tegar menghadapi tugas sampai tuntas atau memecahkan masalah atau bagaimana menyesuaikan perubahan yang terkait erat dengan lingkungan yang mempengaruhi kinerja, menurut dari Rahman (2013). Dan menjelaskan juga apa arti dari minat, minat adalah sikap yang membuat seseorang senang akan objek kecenderungan atau ide-ide tertentu. Sedangkan menurut Hurriyati (2010) yang dikutip dari bukunya Bauran Pemasaran dan Loyalitas Konsumen yang mendefiniskan karakterisitik individu merupakan suatu proses psikologi yang mempengaruhi individu dalam memperoleh, mengkonsumsi serta menerima barang dan jasa, serta pengalaman karakteristik individu merupakan faktor internal (interpersonal) yang menggerakkan dan mempengaruhi perilaku individu. Sedangkan menurut dari Robbins (2015) mengatakan bahwa karakteristik indiviu mencakup usia, jenis kelamin, tingkat pendidikan, status perkawinan, dan masa kerja di organisasi.

Sumber daya yang terpenting dari sebuah organisasi atau perusahaan adalah sumber daya manusia, setiap manusia mempunyai karakteristik individu yang berbeda- beda antara satu dengan yang lainnya. Karena mereka berasal dari daerah yang tidak sama, jenis kelamin yang tidak sama, dan dari latar belakang yang tidak sama pula. Dari beberapa pengertian di atas maka dapat disimpulkan bahwa karakteristik individu adalah perbedaan individu yang melatar belakangi setiap perbuatan dan sikap sehingga antara satu dan yang lainnya di setiap individu tidak akan sama. Karakteristik yang dimiliki oleh individu akan dibawa individu tersebut memasuki suatu lingkungan yang baru, yaitu 
organisasi atau perusahaan dimana dia bekerja. Suatu organisasi atau perusahaan juga pasti memiliki karakteristik sendiri, jadi mungkin akan terjadi ketidak sambungan antara karakteristik individu dengan perusahaan atau organisasi.

Faktor-faktor yang mempengaruhi karakteristik individu, antara lain :

1. Ciri-ciri biologis Yaitu faktor yang berdasarkan atas keturunan seperti yang di kemukakan oleh Hurriyati (2010). Faktor ini merupakan faktor yang paling mendasar, karena merupakan karakteristik bawaan yang merupakan turunan yang dimiliki sejak lahir, baik yang menyangkut biologis maupun faktor psikologis. Faktor ini mencakup, antara lain:

a. Umur. Umur adalah lama waktu hidup atau ada sejak di lahirkan atau diadakan.

b. Jenis kelamin. Jenis kelamin merupakan perbedaan bawaan dari Tuhan sebagai mahkluk ciptaan Nya. Tidak ada perbedaaan yang konsisten antara pria dan wanita dalam kemampuan memecahkan permasalahan.

c. Status perkawinan. status perkawinan adalah ikatan lahir batin antara pria dan wanita sebagai suami istri dengan tujuan membentuk keluarga yang bahagia dan kekal berdasarkan Ketuhanan Yang Maha Esa.

2. Kepribadian menurut dari Ardana dkk (2012) kepribadian yaitu faktor psikologi yang membentuk suatu individu, yang berhubungan dengan interaksi ke individu yang lain.

3. Kemampuan adalah kapasitas seseorang untuk melaksanakan beberapa kegiatan dalam suatu pekerjaan, seperti yang di jelaskan oleh Robbins (2015). Untuk mencapai tujuan dari perusahaan diperlukan kemampuan yang terstruktur untuk mengeksploitasi kinerja-kinerja yang menghasilkan produktivitas.

4. Pembelajaran yaitu proses perubahan yang relatif konstan dalam tingkah laku yang terjadi karena adanya pengalaman atau latihan, menurut dari Hurriyati (2010). Belajar tidak hanya mengubah sikap dan pikiran tetapi yang lebih penting lagi, belajar harus bisa perilaku subjeknya.

5. Sikap menurut dari Robbins (2015) sikap merupakan pernyataan evaluatif baik yang menyenangkan maupun yang tidak tentang suatu objek, orang atau peristiwa. Dengan saling memahami sikap individu maka perusahaan dapat berjalan baik dan tujuan perusahaan dapat tercapai.

6. Persepsi Menurut dari Thoha (2012) persepsi pada hakikatnya adalah proses kognitif yang di alami oleh setiap orang di dalam memahami informasi tentang lingkungannya, baik melewati penglihatan, pendengaran, penghayatan, perasaan dan penciuman.

7. Stress yaitu kondisi dimana tidak sinkronnya mental dan fisik individu, yang biasa menyebabkan menjadi tidak produkti individu tersebut dalam perusahaan.

Menurut Arief Subyantoro (2014) menyebutkan bahwa setiap orang mempunyai pandangan, tujuan, kebutuhan dan kemampuan yang berbeda beda satu sama lain. Karakteristik individu dapat di identifikasi melalui beberapa spesifikasi berikut ini:

a. Kemampuan adalah suatu kapasitas individu untuk melaksanakan berbagai tugas dalam suatu pekerjaan yang terdiri dari kekuatan fisik, dan kemampuan intelektual. Kemampuan fisik adalah kemampuan yang diperlukan untuk melaksanakan tugas- 
tugas yang menuntut stamina. Kemampuan intelektual adalah analisis karakteristik individu, komitmen organisasi, dan kemampuan dari pendidikan formal.

b. Kebutuhan. Kebutuhan adalah jumlah keperluan yang baik yang dapat bersifat fisiologis, psikologis, maupun sosiologis yaitu tingkat kebutuhan pangan, sandang, papan, rohani dan tingkat sosial.

c. Sikap. Sikap adalah kesiap siagaan mental yang dipelajari dan di organisasi melalui pengalaman dalam mendukung usaha pencapaian tujuan perusahaan.

d. Minat. Minat (interest) adalah sikap yang membuat orang senang akan objek situasi atau ide-ide tertentu. Hal ini diikuti oleh perasaan senang dan kecenderungan untuk mencari objek yang disenangi itu. Pola-pola minat seseorang merupakan salah satu faktor yang menentukan kesesuaian orang dengan pekerjaannya.

Berdasarkan uraian di atas, dan penelitian terdahulu, maka bisa disusun hipotesis karakteristik individu mempunyai pengaruh yang signifikan terhadap kinerja karyawan pada PT. Karya Indah Alam Sejahtera di Gresik

\section{METODE PENELITIAN}

Dalam menjalankan sebuah penelitian, baik itu penelitian kuantitatif maupun penelitian kualitatif tidak terlepas dari objek penelitian yang di teliti. Beberapa ahli menerangkan bahwa objek dari penelitian itu adalah seluruh hal yang berhubungan dengan apa yang akan kita teliti. Menurut Sugiyono (2014) menjelaskan tentang populasi dalam bukunya populasi yaitu keseluruhan subjek maupun objek penelitian yang mempunyai kualitas dan karakteristik tertentu. Sedangkan menurut dari Arikunto (2013) menyatakan populasi adalah keseluruhan subjek penelitian. Dengan melihat penjelasan tentang pengertian populasi, maka dapat diambil kesimpulan bahwa populasi adalah semua komponen yang berada di wilayah penelitian. Berdasarkan definisi tersebut, maka populasi dalam penelitian ini adalah 523 orang yang termasuk dalam karyawan internal perusahaan PT. Karya Indah Alam Sejahtera di Gresik. Setelah menentukan populasi sejumlah 523 orang, maka peneliti akan menentukan sampel dari populasi. Dengan harapan sampel yang diambil mampu mewakili seluruh populasi yang ada.

Sampel adalah sebagian atau wakil dari populasi yang diteliti, menurut dari Arikunto (2013), sedangkan menurut dari Sugiyono (2014) sampel adalah bagian atau jumlah dan karakteristik yang dimiliki oleh populasi. Jadi sampel adalah contoh yang diambil dari sebagian populasi penelitian yang dapat mewakili populasi. Walaupun yang diteliti adalah sampel, tetapi hasil dari penelitian atau kesimpulan peneliti berlaku untuk populasi. Dengan melihat dari jumlah populasi yang banyak, maka peneliti melakukan pengambilan sampel dengan menggunakan rumus Slovin. Dengan demikian jumlah sampel yang digunakan dalam penelitian ini berjumlah 84 orang sesuai dengan hasil dari Rumus Slovin. Penelitian ini metode atau cara pengumpulan data yang di lakukan oleh peneliti adalah menggunakan metode angket atau kuisioner. Metode ini dipilih oleh peneliti dikarenakan kebutuhan data nya adalah data yang primer, dan menggunakan skoring pada jawaban yang di isi pada pernyataan yang di buat oleh peneliti. Dengan 
IMKA Implementasi Manajemen \& Kewirausahaan - April, Vol. 1, No. 1, 20-29, 2021

pengumpulan data yang menyatakan variabel-variabel yang menggambarkan persepsi para karyawan terhadap kompensasi, lingkungan kerja dan produktivitas.

\section{HASIL DAN PEMBAHASAN}

Berdasarkan hasil analisis deskriptif variabel penelitian, didapatkan bahwa semua variabel yang meliputi lingkungan kerja, karakteristik individu dan kinerja karyawan PT. Karya Indah Alam Sejahtera berada pada kondisi baik. Berdasarkan hasil analisis data lingkungan kerja secara parsial mempunyai pengaruh yang signifikan terhadap kinerja karyawan. Hal ini ditunjukkan dengan nilai t sebesar 3.501 dengan tingkat signifikansi sebesar 0.001, dimana nilai signifikansi ini lebih kecil dari 0,05. Sehingga apabila ada perubahan pada lingkungan kerja berpengaruh signifikan terhadap peningkatan dan penurunan kinerja karyawan. Oleh karena itu, apabila perusahaan ingin meningkatkan kinerja karyawan dapat dilakukan dengan meningkatkan lingkungan kerja, karena lingkungan kerja mempunyai pengaruh yang positif dan signifikan terhadap kinerja karyawan dengan cara mengurangi kebisingan ditempat kerja karena kebisingan ini mempunyai korelasi yang paling tinggi sebesar 0,697 dari pada indikator lingkungan kerja lainnya.

Begitu juga pada karakteristik individu yang juga mempunyai pengaruh signifikan terhadap kinerja karyawan dengan tingkat signifikansi sebesar 0.048, dimana nilai signifikansi ini lebih kecil dari 0,05. Sehingga apabila ada perubahan pada karakteristik individu akan berpengaruh signifikan terhadap peningkatan dan penurunan kinerja karyawan. Oleh karena itu, apabila perusahaan ingin meningkatkan kinerja karyawan dapat juga dilakukan dengan meningkatkan karakteristik individu karyawan, karena karakteristik individu mempunyai pengaruh yang positif dan signifikan terhadap kinerja karyawan dengan cara meningkatkan minat karyawan dalam bekerja karena minat ini memiliki nilai korelasi yang paling tinggi sebesar 6,86 dibandingkan dengan indikator karakteristik individu lainnya.

Berdasarkan hasil analisis data lingkungan kerja dan karakteristik individu secara simultan mempunyai pengaruh yang signifikan terhadap kinerja karyawan. Hal tersebut ditunjukkan dari nilai signifikansi 0,01, dimana nilai signifikansi ini kurang dari 0,05. Oleh karena itu ketika ada perubahan pada lingkungan kerja dan karakteristik individu secara simultan, maka akan berpengaruh signifikan pada kenaikan dan penurunan kinerja karyawan PT. Karya Indah Alam Sejahtera. Kinerja karyawan dapat dipengaruhi oleh kontrinusi dari variabel lingkungan kerja dan karakteristik individu dilihat dari nilai $\mathrm{R}$ Square sebesar 0.167 atau sebesar 16,7\% variabel kinerja karyawan dapat dijelaskan oleh variabel pelatihan dan lingkungan kerja, sedangkan sisanya sebesar $83.3 \%$ dijelaskan oleh variabel lain diluar peneltian ini. 


\section{KESIMPULAN}

Berdasarkan hasil analisa dan pembahasan yang sudah dilakukan, maka dapat disimpulkan sebagai berikut: Lingkungan kerja, karakteristik individu dan kinerja karyawan di PT. Karya Indah Alam Sejahtera semuanya dalam kondisi baik. Lingkungan kerja mempunyai pengaruh yang signifikan dan positif terhadap kinerja karyawan PT. Karya Indah Alam Sejahtera. hal ini dapat dibuktikan dari nilai t sebesar 3.501 dengan tingkat signifikansi sebesar 0.001. Karakteristik individu mempunyai pengaruh yang signifikan dan positif terhadap kinerja karyawan PT. Karya Indah Alam Sejahtera. hal ini dapat dibuktikan dari nilai t sebesar 1.922 dengan tingkat signifikansi sebesar 0.048. Lingkungan kerja dan karakteristik individu secara simultan mempunyai pengaruh yang signifikan dan positif terhadap kinerja karyawan PT. Karya Indah Alam Sejahtera. hal ini dapat dibuktikan dari nilai uji $\mathrm{F}$ hitung sebesar 8.143 dengan tingkat signifikansi sebesar 0.001 .

\section{DAFTAR PUSTAKA}

Ardana . (2012). Manajemen Sumber Daya Manusia . Yogyakarta : Graha Ilmu Kaswan. (2012). Manajemen Sumber Daya Manusia. Yogyakarta: Graha Ilmu Mangkunegara, A.A. P. (2012). Manajemen Sumber Daya Manusia. Bandung: PT. Remaja Rosdakarya.

Mangkunegara, A.A. P.. (2011). Manajemen Sumber Daya Manusia. Bandung: PT. Remaja Rosdakarya.

Rahman, A. A. (2013). Psikologi Sosial: Integrasi Pengetahuan Wahyu dan Pengetahuan Empirik. Jakarta: Rajawali Pers.

Ratih, H. (2010). Bauran Pemasaran dan Loyalitas Konsumen. Jakarta: Alfabeta CV

Robbins, S.P. \& Judge, T.A. (2015). Perilaku Organisasi Edisi Enam Belas, Penerjemah : Ratna Saraswati dan Febriella Sirait Jakarta : PT. Salemba Empat.

Sedarmayanti. (2011). Manajemen Sumber Daya Manusia, Reformasi Birokrasi dan Manajemen Pegawai Negeri Sipil (cetakan kelima). Bandung : PT. Refika

Sofyan, D. K. (2013). Pengaruh Lingkungan Kerja Terhadap Kinerja Kerja Pegawai BAPPEDA. Malikussaleh Industrial Engineering Journal, 2(1), 230-244.

Subyantoro, A. (2014). Pengaruh Karakteristik Individu, Karakteristik Pekerjaan, Karakteristik Organisasi Terhadap Kepuasan Kerja dan Motivasi Kerja (Studi pada Pengurus KUD di Kabupaten Sleman). Jurnal Manajemen dan Kewirausahaan, Vol. 11, 21-30.

Sugiyono. (2013). Metode Penelitian Kuantitatif Kualitatif dan $R \& D$. Bandung : Alfabeta.

Sugiyono. (2014). Metode Penelitian Manajemen . Bandung: Alfabeta

Sugiyono. (2016). Metode Penelitian Kuantitatif Kualitatif dan R\&D . Bandung : Alfabeta

Suharsimi, A. (2013). Prosedur Penelitian : Suatu Pendekatan Praktik. Cetakan kelima belas. Jakarta : Rineka Cipta

Thoha, M. (2012). Perilaku Organisasi; Konsep Dasar Dan Aplikasinya. Jakarta: Rajawali Pers

Wibowo . (2016). Manajemen Kinerja Edisi Kelima . Jakarta : Raja Grafindo Persada 